\title{
Cell-Mediated Cytotoxicity
}

National Cancer Institute

\section{Source}

National Cancer Institute. Cell-Mediated Cytotoxicity. NCI Thesaurus. Code C17709.

Any of the processes involved in cytolysis of a target cell by effector lymphocytes, such as cytotoxic T lymphocytes or NK cells; it may be antibody-dependent or independent. 